\title{
Society participation in the village fund program for development in Kletek village, Central Malaka sub-district, Malaka regency
}

\author{
Jimy Handry Nahak ${ }^{1}$, Petrus Kase ${ }^{2}$, Pius Bumi Kelen ${ }^{3}$ \\ Nusa Cendana University, Indonesia ${ }^{1,2,3}$ \\ ¡imyhandrynahak@gmail.com ${ }^{l}$, kasepetrus@yahoo.co.id ${ }^{2}$, piusbumikellen@gmail.com ${ }^{3}$
}

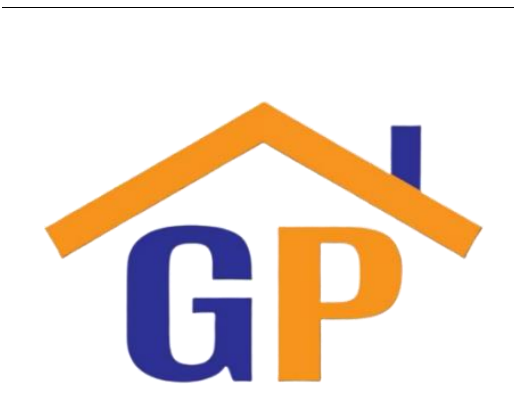

\begin{abstract}
Purpose: The purpose of this research was to describe and analyse society participation in the Village Fund for Development Program in Kletek Village, Central Malaka District, Malaka Regency.
\end{abstract}

Research Methodology: This research is qualitative in nature. The informants who were selected purposively were 21 people.

Results: The findings in this study are that society does not participate because the village apparatus is less open in capturing society's aspirations, and there is no publication to the society so that it appears that government officials tend to be closed off about the use of funds.

Article History

Received on 1 December 2020

$1^{\text {st }}$ Revision on 11 January 2021

$2^{\text {nd }}$ Revision on 21 January 2021

Accepted on 1 February 2021
Limitations: The limitation of this research is that the research only focuses on the Kletek Village society's participation in the Village Fund Program.

Contribution: This research becomes scientific information for public administration program.

Keywords: Participation, Decision making, Implementation, Use, Evaluation

How to cite: Nahak, J. H., Kase, P., \& Kelen, P. B. (2021). Society participation in the village fund program for development in Kletek Village, Central Malaka sub-district, Malaka Regency. Annals of Human Resource Management Research, 1(1), 55-67.

\section{Introduction}

The Government of the Unitary State of the Republic of Indonesia today continues to make various efforts to increase the implementation of national development in order to balance the pace of development in the regions. The Indonesian government continues to make various efforts to run the pace of development in urban and rural areas in a balanced manner. This government effort is nothing but a follow-up to Indonesia's principles as set out in the fourth preamble to the Republic of Indonesias Constitution of 1945 which reads "Protecting the entire Indonesian nation and all Indonesian blood and advancing public welfare, educating the nation's life, and participate. in implementing a world order based on peace and social justice ". This great mandate cannot be carried out centrally by the Central Government. The territory of Indonesia, which is an archipelago, makes each region different from other regions including its development needs. Therefore, efforts to decentralise development by granting regional autonomy are a breakthrough and the right solution for national development in Indonesia. With regional autonomy, it is hoped that national development can proceed according to each region's needs.

According to Dewi (2019), regional autonomy is meant to speed up economic growth and regional progress, reduce regional inequalities and enhance public service delivery so that they are more effective and responsive to the future needs and features of individual regions. The right, jurisdiction and the duty of an autonomous region to manage and administer government affairs and local populations' interests in compliance with constitutional legislation was laid down in Article 1 subsection 5 of Law Number 23 of 2014 on regional autonomy. Decentralisation, however, which could put the population closer to decision-making, has not had a real impact on major changes in 
participatory policy making.

One of the advantages of regional autonomy is the ability to govern and administer villages and local councils based on the village communities' social initiatives, traditions, and socio-cultural principles. (Mohammad et.al, 2020). Village autonomy as regulated in Law No. 6 of 2014 concerning Villages is strong evidence that legally the format of decentralisation and regional autonomy policies has touched the lowest level of government, namely the Village level. With the existence of Law No. 6/2014 on Villages, the village government can freely regulate village households based on the 13 principles contained in Article 3, which are as follows: (1) Recognition, namely recognition of the rights of origin; (2) Togetherness, namely the spirit to play an active role and cooperate with the principle of mutual respect between institutions at the Village level and elements of the Village society in developing the Village; (3) Subsidiarity, namely the determination of local scale authority and local decision making for the benefit of the Village society; (4) Diversity, namely recognition and respect for the value system prevailing in the Village society, but still observing the shared value system in the life of the nation and state; (5) Mutual cooperation, namely the habit of helping each other to build the Village; (6) Kinship, namely the habit of Village society members as part of a large family unit of the Village society; (7) Deliberation, namely the process of decision making concerning the interests of the Village society through discussions with various interested parties; (8) Democracy, namely the system of organising village communities in a government system carried out by the village society or with the approval of the village society and the dignity of humans as creatures of God Almighty are recognised, organised, and guaranteed; (9) Independence is a process carried out by the Village Government and the Village society to carry out an activity in order to fulfill their own needs; (10) Participation, namely taking an active role in an activity. (11) Equality, namely equality in position and role; (12) Empowerment, namely efforts to improve the standard of living and welfare of village communities through the establishment of policies, programs and activities in accordance with the essence of problems and priority needs of the village society; and (13) Sustainability, namely a process carried out in a coordinated, integrated, and sustainable manner in planning and implementing Village development programs.

The governance and development process certainly requires funds to support any regional automation process. therefore, in Law number Law Number 6 of 2014, it is stated that the village must have an allocation of funds. In Government Regulation Of The Republic Of Indonesia Number 60 Of 2014 Concerning Village Funds Sourcing From State Revenue And Expenditure Budget stated that the Village Fund is an annual budget in the State Revenue And Expenditure Budget, which is distributed to each village as a source of village income. This policy also integrates and optimises all existing schemes for budget allocation from the Government to villages that have been around so far.

Based on Law No. 6 of 2014, the village has a source of income namely in the form of village original income, sharing of regional taxes and retribution for districts / cities, part of the central and regional financial balancing funds received by districts / cities, budget allocation from the Revenue Budget and State Expenditure, financial assistance from the provincial Revenue and Expenditure Budget and Regency / City Regional Revenue and Expenditure Budget, as well as grants and contributions that are not binding on third parties. The overall source of village income is used to fund village authority implementation, which includes administration, governance, development, society and society empowerment (Samosir, 2020). One of the government's strategies is to help villages become independent and autonomous by providing village funds.

Development in a region can be realised if there is the participation and cooperation of the whole society, one of the factors that determine the implementation of a development is the human factor itself. In the implementation of development, society participation is highly expected in every development stage, starting from the planning stage, the implementation stage, the utilisation stage, and the evaluation stage. Through this society participation-based development, regional development will be carried out following society's needs and aspirations.

Community involvement in the implementation of activities with a self-management pattern is very important because it is one of the important things and can be applied in the management of the Village Fund, the use of local labor, and the use of local raw materials in the village. With a selfmanagement pattern, efforts to plan and implement these activities are carried out independently by the village. The money used for development does not flow out of the village. By using local labor, it is hoped that the implementation of these activities can absorb the workforce in the village and 
provide income for those who work. Meanwhile, local raw materials are expected to provide income to the raw material supply sector in the village or managed by the village community themselves. As previously mentioned, one of the most important aspects of government administration, especially development management, is planning.

Abe (2005: 18) explains that people's involvement in the planning process is in the general formulation process, where the people are given the opportunity to propose basic hopes, needs and interests. In this framework planning can be a vehicle for changing the old political scheme from the top down to the bottom up society involvement in regional development planning will greatly encourage the creation of a good planning result, because the society as one of the elements in development, of course, can know and understand what is in their area. In addition, according to (Riyadi and Bratakusuma 2005: 10), by involving them in the development planning process, the government has given trust to the society, so that they can feel responsible and feel that they have development programs that are clearly very beneficial for the implementers. Society involvement in development planning is often referred to as society participation. This is as stated by Sastrodipoetro in Safi'i (2007: 74). Participation is defined as the active involvement of local communities in decision-making or implementation of development projects. However, in its implementation, the bottom up planning pattern, which prioritises society participation, has not progressed as expected.

The Village Fund's existence has driven many successes, but this does not mean that the implementation and management of the Village Fund is running smoothly. A problem is a gap between the Village Fund's hopes or goals (das sollen) and the reality on the ground (das sein). Based on observations and dialogues with several Kletek villagers, some facts that often occur are revealed. Some facts that can be disclosed include (1) Society participation in decision making is still considered very minimal, this can be seen from the level of society attendance so far in the MusrembangDes that only ranges from $30-50 \%$ of the target society invited to attend, (2) Society participation in the implementation is felt to be still lacking, this is because the society does not volunteer to assist in the form of material items such as money, local work materials, work tools and land that will later open alleys or roads, (3) Society participation in taking benefits is deemed not right on target, and (4) society participation in the evaluation is still lacking, this is because the village apparatus does not pay attention to evaluation activities.

Some of the facts above clearly show that the society is less participatory and less empowered. This clearly contradicts the Regulation of the Minister of Villages, Development of Disadvantaged Areas, and Transmigration (PERMENDES PDTT) No. 16 of 2018 concerning Priority for the Use of Village Funds in 2019 article (1) paragraph 10, which states that village funds are an empowerment program for village communities. According to Purnomo et.al, (2016) village society empowerment is an effort to develop society independence and welfare by increasing knowledge, attitudes, skills, behavior, capacity for awareness and utilising resources through the establishment of program policies, activities and assistance in accordance with the essence of problems and priority needs of the village society; furthermore in article (3) regarding the basic principles of priority for the use of village funds, point (e) the principle of Participation: prioritises initiative, creativity and the participation of village communities; and article (13) paragraph (1) The priority of using the Village Fund in the field of Village development and empowering the Village community must be announced by the Village Government to the Village community in the public space so that it can be accessed by the Village community.; paragraph (2) Publication of the use of Village Funds is carried out in a selfmanaged and participatory manner by involving the participation of the Village society; and article (3) In the event that the Village does not publish the use of Village Funds in the public space, the Regency / City Government shall impose administrative sanctions in accordance with the provisions of the legislation. Najih, et.al (2006: 75) stated that the experiences that have occurred as a result of the low involvement of the society in the development planning process have resulted in negative impacts, including: (1) a low sense of belonging to the society for the development programs/projects that have been prepared, which resulted in the sustainability of the program/project being implemented not being realised; (2) the emergence of prohibitive transaction costs because the society does not understand the objectives of the development program/project, resulting in rejection of the program/project being implemented; (3) Regional development programs/projects that are not following the needs and characteristics of the society; (4) diminishing public trust in the government; and (5) pollution and or environmental damage. The same thing was stated by Rahadhan and Bahtiar 
(2006: 119); "There are many cases that the development results are not in accordance with the needs and even not desired by the society at the village level, as a result the society is directly affected, such as conflicts of interest between stakeholders, so that the order of society life is out of control and even leads to irrational demands". Researchers in this study feel interested in researching Society Participation in the Village Fund Program for Development in Kletek Village, Central Malaka SubDistrict, Malaka Regency.

\section{Literature review}

\subsection{Good Governance}

Good governance, seen from the equivalent word, comes from the main Latin language, namely Gubernare (government), then absorbed by English to become Govern (rule), then develops with new word models such as Steer (driving, controlling), Direct (directing), or Rule (Reign). Good governance as a form of development management, also known as development administration, places the central government's role as the Agent of Change of a developing society in a developing country. Agent of change due to the change that he wants, to become a Planned Change, it is also called Agent of Development. Agent of Development is defined as driving the development process and changes in the nation's society. The government pushes through policies and programs, projects, and a planning role in the budget.

O'Brien (Nugroho; 2005: 142) defines Good Governance as the sum of the ways in which individuals and institutions both private and public manage affairs with them. According to the World Bank (Wahab 2002: 34), Good governance is a term for robust, accountable growth administration in accordance with democracy and competitive markets, avoiding misallocation and scarce investment and preventing corruption both political and administrative, implement budget discipline and create a legal framework for the growth of entrepreneurial activities. In addition, the World Bank also synchronises good governance as a synergistic and constructive relationship between the State, the private sector and society.

Mardiasmo in Tangkilisan (2005: 114) argues that governance, which is oriented in the development of the public sector, is to create good governance, where the basic meaning is good governance. This condition seeks to create a solid and responsible development administration in line with the principles of democracy, efficiency, prevention of corruption, both politically and administratively. According to the UNDP policy document, it states: Governance is the use of economic, political and administrative powers to manage State affairs at all levels. Governance includes all mechanisms, processes and institutions by which citizens and society groups express their interests, exercise legal rights, and fulfill obligations and bridge differences between them. It is clear that good governance is a matter of balancing the state, market and society.

Law No. 28/1999 concerning Clean Governance and Free from Collusion, Corruption and Nepotism (Law No. 28/1999). In Article 1 paragraph (6) Law no. 28/1999 explained "the General Principles of Good State Governance are principles that uphold the norms of decency, obedience and legal norms, in order to create a State Administration that is clean and free from corruption, collusion and nepotism". The general principles of good governance in realising good governance (good governance) in regional government, then the regional government as the main element of government administration, which is the protector and servant of the society, should uphold the General Principles of Good State Governance.

\subsection{Society participation}

The word participation comes from the English word "participation" which means taking part, participation (Echols \& Shadily, 1990). According to Sumaryadi (2010: 46) Participation means the participation of a citizen or community in the growth process by giving insight into proposals, energies, time, skills, money and materials or taking advantage of and enjoying the outcomes of development. In the development process a person is participating in the development process. The definition of participation put forward by Djalal and Supriadi (2001: 201-202) where participation can also mean that the decision maker suggests that the group or society participate in the form of ideas and thoughts, items, expertise, materials and services. Participation may also contribute to community awareness of their own problems, analysis of their choices, decision-making, and problem-solving.

Mikkelsen in Isbandi (2007: 27) divides participation into 6 definitions stated in the participatory 
planning book based on society assets, namely: (1) Participation is a voluntary contribution from the society to the project without participating in decision making; (2) Participation is "Sensitising" (sensitising) the society to increase the willingness to accept and the ability to respond to development projects; (3) Participation is voluntary involvement by the society in changes that it determines itself; (4) Participation is an active process, which means that the person or group involved, takes the initiative and uses their freedom to do so; (5) Participation is the strengthening of dialogue between local communities and staff who carry out project preparation, implementation and monitoring in order to obtain information on the local context and social impacts; and (6) Participation is society involvement in the development of themselves, their lives and their environment.

Tilaar (2009: 287) states that Participation is an expression of the will to develop democracy in the process of decentralisation, where attempts are made to incorporate the need for a basic strategy through the participation of society in the planning and growth process of their communities.

Sundariningrum in Sugiyah (2001: 38) classifies participation into two based on its involvement, namely: (1) Direct Participation, which means participation that occurs when individuals perform certain activities in the participation process and (2) Participation is indirect, it means participation that occurs when individuals delegate their right to participate. According to Sjahrir in Muluk (2007: 51-52), the notion of participation in development is not merely participation in the implementation of development programs, plans and policies, but also emancipatory participation. This means that wherever possible the determination of the allocation of economic resources is increasingly referring to the development motto of, by and for the people.

Cohen and Uphoff (1977: 6) distinguish participation into four types, namely first, participation in decision-making. This participation is mainly concerned with determining alternatives to society regarding ideas or ideas of common interest. Participation in this decision-making includes contributing ideas or thoughts, attendance at meetings, discussions and responses or rejection of the programs offered; Second, participation in Implementation, which includes mobilising financial resources, administrative activities, coordination and program description. Participation in implementation is a continuation of plans that have been previously initiated, whether related to planning, implementation or objectives; Third, participation in taking advantage (participation of benefits). Participation in taking benefits cannot be separated from the implementation results that have been achieved both in terms of quality and quantity. In terms of quality it can be seen from the output, while in terms of quantity it can be seen from the percentage of program success; and Fourth, participation in evaluation (participation of evaluation). Participation in this evaluation is related to the implementation of programs that have been planned previously.

Participation in this evaluation aims to determine the achievement of the previously planned program. Researchers see and study some of the previous definitions, so it can be said that participation is the involvement of an individual or group in achieving goals and the sharing of authority or shared responsibility.

\subsection{Financial management}

Companies in achieving the desired goals must carry out its functions properly. Financial management has significance in all types of business, such as banking and other financial institutions as well as industrial and retail companies. Management can be defined as a variety of practices in order to accomplish corporate objectives efficiently and effectively (including preparation in decision making, organisation, leadership, and management) on organisation's capital (human, financial, physical and information) (Griffin, 2004 in Nastiti and Suntoyo, 2012). Financial management manages the financial function consisting of investment decisions, funding decisions and asset management decisions. Financial management applies to the corporate operations relating to the accumulation and administration of funds and assets in compliance with the general organisation priorities.

Asnaini (2012: 1) says financial management is a process in regulating financial activities or activities in an organisation, which includes planning, analysing and controlling financial activities which are usually carried out by financial managers or can be interpreted as activities relating to attempts to procure company funds by reducing the expense and commitment to effectively use and assign those funds to optimise business profit, namely the pricing for which potential customers are 
able or ready to pay when they are delivered to a corporation.

\subsection{State financial management}

Geodhart in Sulaiman (2011: 20) argues that state finances are all laws that are established periodically that give the government power to carry out expenditures regarding a certain period and show the means of financing needed to cover these expenses. Geodhart divides the elements of State finance, namely including: periodic elements, elements of government as budget executor, elements of budget implementation include two powers, namely expenditure authority and the authority to explore sources of financing to cover the expenses concerned; and the element of the form of the state budget is in the form of a law.

Due (in Tjandra, 2006: 1-2) says a budget is a financial plan for a certain period of time. The Goverment Budget (government budget) is a statement regarding the proposed expenditure or expenditure for the future along with the actual expenditure and revenue data for the future and past periods. The elements of Jhon F. Due's definition include the following: (1) Expenditure budget containing financial data regarding expenditures and revenues from the coming years; (2) The amount proposed for the coming year; (3) Number of estimates for the current year; and (4) The financial plan is for a certain period. In connection with the definition of state finance, according to Jhon F. Due, the definition of state finance is the same as the budget (budget). Judging from the state budget position in state administration, it is understandable, however, if it is linked to the Revenue and Expenditure Budget (APBN).

Atmadja (1986: 49) defines state finances as the public funds that only come from the state budget in regard to transparency by the government that state finances that must be paid for by the government. So what State finance entails is finance that comes from the government's budget.Atmadja describes the dualism of state finance's definition, namely the definition of state finance in a broad sense and the definition of state finance in a narrow sense. In a broad sense, the definition of state finance means finance originating from the APBN, APBD, Finance for State Business Units or state-owned companies, and essentially all state assets. Meanwhile, the definition of state finance in the narrow sense is finance originating from the APBN only.

Asshiddiqie (2008: 833) argues that activities related to income and expenditure were initially understood as state finance which was later reflected in the formulation of the provisions of the 1945 Constitution of the Republic of Indonesia which was compiled in 1945. Therefore, it can be said that initially, what is meant by state money or finances in the 1945 Constitution of the Republic of Indonesia before the amendment is the state revenue and expenditure budget only. In this narrow sense it is assumed that all state revenues, their entry and exit, are calculated entirely through the state revenue and expenditure budget. There is no other money, which is included in the definition of state money outside the state revenue and expenditure budget. Furthermore, Asshiddiqie (2008: 834) stated that the state revenue and expenditure budget have two aspects: the calculation of state revenue and state expenditure calculation. The form or format, the preparation of the state revenue and expenditure budget is outlined in the form of a law on the State Revenue and Expenditure Budget.

\subsection{Village}

Village is etymologically derived from the Sanskrit word" Deca" which means homeland, land of origin or land of birth (Syahruddin et al, 2019). According to the Big Indonesian Dictionary, A village is a territory entity that comprises a number of families with their own government structures (headed by a village commander) or a group of households outside the region. The term village is only known in Java, while outside Java, for example in Sumatra, Kalimantan and Sulawesi, the designation for an area with a similar meaning to village is very diverse, according to the origin of the village area, whether based on the principles of genealogical ties or territorial ties and even based on certain functional objectives (such as a farmer village or fishing village, or gold mining village) and so on. Widjaja (2003: 3) in his book entitled "Village Government" states that a village is a legal society unit that has an original structure based on rights of special origins, The basis of thought regarding Village Government is diversity, participation, genuine autonomy, democratisation and society empowerment. Zakaria in Sumpeno (2011:3) writes that a village is a group of people who live together in an area, which has a government organisation with a series of self-determined regulations, and is under the leadership of a village that is elected and self-determined. 
Law of the Republic of Indonesia Number 6 of 2014 concerning Villages, article 1 paragraph 1, states that a village is a village and customary village or what is referred to by another name, hereinafter referred to as village, is a legal society unit that has territorial boundaries which is authorised to regulate and administer government affairs, interests of the local society based on society initiatives, rights of origin, and / or traditional rights that are recognised and respected in the government system of the Republic of Indonesia.

Daldjoeni (1987: 44) said that the village in a general sense can also be said to be a human settlement that is located outside the city and its inhabitants make a living by farming or farming. The village can also be said to be the result of a combination of a group of humans' activities with their environment. The result of this combination is a form or appearance on earth caused by physiographic, social, economic, political and cultural elements that interact with each other between these elements and in relation to other areas (Bintarto, 1986: 11).

Bintarto (1986: 12) in his book, Village City Interaction, Mangatakan village has several functions, including: (1) In relation to the city, the village which is a Hinterland or a supporting area functions as an area that provides staple foodstuffs such as rice, corn, cassava, apart from other food ingredients such as beans, soybeans, fruits and other foodstuffs of animal origin; (2) In terms of economic potential, the village functions as a storage area for raw materials and labor; and (2) In terms of work activities, a village can be an agricultural village, a manufacturing village, an industrial village, a fishing village and so on. Furthermore, Bintaro explained that the village has two potentials, namely: (1) The physical potential of the village includes, among others: First, land, in the sense of mining and mineral resources, plant sources which are a source of livelihood and livelihood; Second, water, in the sense of water sources, the state or quality of water and its water management for irrigation, agriculture and daily needs; Third, climate, which is an important role for agrarian villages; Fourth, livestock, in terms of the function of livestock in the village as a source of energy, a source of food and a source of finance; and Fifth, humans, in terms of work as land processors and as producers; (2) Village Non-Physical Potentials, among others are: First, village communities that live based on mutual cooperation and can constitute a productive power and building strength based on cooperation and mutual understanding; Second, social institutions, education and village social organisations that can provide social assistance and guidance in a positive sense; and Third, the village apparatus or civil servants are the source of the smooth and orderly village administration.

Government Regulation Number 72 of 2005 concerning Villages, Article 6 specifies that in governing and administering local society rights on the basis of local origins and traditions, the Village Government and the Village Consular Office shall administrate governmental affairs in the State Government system of Republic of Indonesia. The researcher concluded that the village is a community unit authorised by the national government framework to administer and handle local communities' needs, in compliance with their origin and local customs. and are located in the subdistrict area and are led by the village head with several village officials.

\subsection{Village fund}

Villages have the authority to carry out their own government activities with the aim of accelerating growth and development. To exercise this authority, the village government has sources of revenue that are used to finance the activities it carries out. According to Government Regulation (PP) No. 8 of 2016 explained that the source of village financial income consists of: Village Original Income (Village Wealth Results, Society Self-Help Results, Pungutan, Gotong Royong); Distribution of District Taxes and Retribution; District Central and Regional Balancing Funds or Village Fund Allocation; Financial grants from provincial and district governments; Grants and donations from binding third parties.

Several things cause a village to need a source of income, namely: (1) The village has a small Village Budget (APBDes) and its source of income is very dependent on very little assistance; (2) Low welfare of the village society, making it difficult for villages to have high Village Original Income (PADes); (3) This problem was followed by low village operational funds for running public services; and (4) Many development programs enter the village but are only managed by the Dinas. Such programs get criticism because the program does not provide access to learning for the village, and the program is top down so that it is not in line with the needs of the village and its society (Putra et al; 2013). Responding to these problems, the government provides financial support to villages, one 
of which is derived from a Financial Balancing fund between the Central Government and Regional Government of at least 10 percent earmarked for villages called Village Funds. The purpose of providing the Village Fund is actually a stimulant aid or stimulant fund to encourage the financing of village government programs supported by society's self-help participation in carrying out government activities and society empowerment.

Government Regulation No. 60/2014 states that Village funds are funds derived from the State Revenue and Expenditure Budget (APBN), which are used for financing governance, infrastructure, development in society, and social empowerment in villages transferring them through Regional Revenue and Expenditure Budget. Village Revenue and Expenditure Budget, hereinafter referred to as APBDesa, is the annual financial plan of the Village government.

Regulation of the Minister of Villages, Development of Disadvantaged Areas and Transmigration (PERMENDES PDTT) No. 16 of 2018 concerning Priority for the Use of Village Funds in 2019, in Article (1) the second point states about Village Funds sourced from the State Budget, that Village Funds are funds sourced from The State Expenditure Budget (APBN) which is allocated for villages is transferred through the Regency / City Regional Expenditure Budget (APBD) and is used to finance governance, implementation of development, society development, and society empowerment. Village Revenue and Expenditure Budget, hereinafter abbreviated as APB Desa, is the annual financial plan of the Village government. Furthermore, in managing the Village Fund, the village government must adhere to the Minister of Finance Regulation (PMK) Number 50 / PMK.07 / $\underline{2017 / 2017}$ concerning Management of Transfers to Regions and Village Funds.

\section{Research methodology}

This research uses a qualitative approach with descriptive methods. Kletek Village was chosen as the research location based on the consideration that the Village Fund Management in Kletek Village has not yet been implemented as stated in the existing laws and regulations where the society feels less involved in development processes in their own village. The problems that have been described previously became the researcher's consideration so that the location selection in Kletek Village, Central Malaka Sub-District, Malaka Regency, East Nusa Tenggara Province became the basis for the researchers' consideration in conducting the study. Researchers in carrying out this research used two types of data collection, namely primary and secondary. The data analysis technique used is the interactive model of Miles and Huberman's theory (in Sugiyono, 2010: 246) where the steps in data analysis are starting from the data collection process, data reduction, and data presentation) and Conclusion Drawing (Conclution).

\section{Results and discussion}

\subsection{Research result}

To find out how society participation in the village fund program for development in Kletek Village, Malaka Tengah District, Malaka Regency, the researcher uses the theory of participation from Cohen and Uphoff (1977: 6) to distinguish participation into four types, namely first, participation in decision making (participation of decision) making). This participation is mainly concerned with determining alternatives to society regarding ideas or ideas of common interest. Participation in this decision-making includes contributing ideas or thoughts, attendance at meetings, discussions and responses or rejection of the programs offered; Second, participation in Implementation, which includes mobilising financial resources, administrative activities, coordination and program description. Participation in implementation is a continuation of plans that have been previously initiated, whether related to planning, implementation or objectives; Third, participation in taking advantage (participation of benefits). Participation in taking benefits cannot be separated from the results of the implementation that have been achieved both in terms of quality and quantity. In terms of quality it can be seen from the output, while in terms of quantity it can be seen from the percentage of program success; and Fourth, participation in evaluation (participation of evaluation). Participation in this evaluation is related to the implementation of programs that have been planned previously. Participation in this evaluation aims to determine the achievement of the previously planned program. Researchers see and study some of the previous definitions, so it can be said that 
participation is the involvement of an individual or group in achieving goals and the sharing of authority or responsibility together. This will be discussed in the results of the research below:

\section{Participation in decision making}

Society participation in meetings that discuss village funds for village development in the implementation of several communities is not involved in decision making during meetings at the hamlet level. After confirming with village officials, it was discovered that decisions at the lower levels were only formalities, and were only made by a few people. There are 3 causes of society absence from meetings at the hamlet to village level, namely: First, the society often thinks that meetings are a waste of time; Second, not all elements were invited to attend the meeting; and third, only people who are considered close and agreeable to the village head are given the invitation.

When expressing their opinions in the society forum, those who attend the MUSREBANGDes often convey their aspirations. There are 2 aspirations, aspirations from groups and individuals. Those aspirations are accommodated in decision-making. Not all aspirations are accommodated and made joint decisions because they have to look at the district, provincial and national development plans. The only aspirations that have been realised are the hand tractor and road proposals.

\section{Participation in implementation}

Society participation in the implementation of work is the active role of society in implementing development programs that use funding from village funds. Society participation at this stage takes the form of donations of labor, materials or tools, forms of work supervision, and the process of building development in the Village

Contribution can be divided into: First, participation in the form of work the society contributes as laborers of the local society. Second is material contribution. In this case the society wants to contribute in the form of materials or tools in development. This is justified in PERMENDES PDTT No. 16/2018 concerning Priority for the use of 2019 village funds.

The society in Kletek Village already understands and participates in making contributions both in the form of labor, materials and tools. However, it is very unfortunate, in accordance with the results of the researcher's observation that the contribution was only made by the elderly, while young people were not involved in work if they were not paid. This is based on their thinking that everything is a project so that if the work means that labor must be paid.

\section{Participation in Benefit-taking}

The accuracy of development targets how many people can benefit from the work. The purpose of development is how many people can enjoy the results of the development and whether the development has been on target. In this study, researchers tried to extract information about society participation in beneficiaries with the indicators. The accuracy of development targets; and how many people can enjoy the results of the work.

In terms of the accuracy of development targets in the village of Kletek it is still deemed inaccurate because society needs that have been conveyed to the village through the MUSREMBANGDes forum are not heard and realised so that the development carried out by the Kletek village government is development that does not accommodate the aspirations of the society but is in accordance with the wishes of the village apparatus. In addition, the timeliness is also not right because of the several cases submitted by the informants in the previous interview, it was shown that fertiliser and medicinal assistance for agriculture was not given before the planting season but was in the harvest season so that the aid was not used entirely by the society.

Development target accuracy is not on target because only certain people or groups receive assistance in the form of agricultural tools. Not on time because assistance was given at the wrong time (fertilisers and agricultural medicines).

People can enjoy the results of that work. Fertilisers and agricultural medicines are not evenly distributed. For roads and deckers, almost all enjoy the results. For the hand tractor, hand sprayer and fall off, only certain people. 


\section{Participation in evaluations}

The village fund program opens space for the society to monitor the implementation of Village development and the administration of Village governance. The active role of the society in monitoring is a form of society participation in the evaluation stage. The evaluation stage in question is the time for the implementation of physical development and to participate in supervising the use of village funds. The indicator used to see society participation in the evaluation is the timeliness of completing development work and delivery of information to the society.

All buildings are still functioning; it is just that the deck's condition has begun to break down. Delivering information to the public. The noticeboard was only made of cardboard. There was never any information on the use of village funds, which was posted on the bulletin board. As previously described in the summary of research findings on society participation in Kletek village, it illustrates that society participation in Kletek village still experiences many problems. This problem creates the impression that they do not trust and are indifferent to development. As a whole, society is not involved in extracting aspirations from the hamlet level. In the village level, Musrembang also only presents people who feel like the village head only. The assistance that is not on time and targets that are not right also raises its own problems regarding society participation and the lack of transparency regarding the use of village funds also makes the Kletek village society trust less of the village head and its officials.

\subsection{Discussion}

Arnstein, through his typology known as the Eight Rungs on The Ladder of Citizen Participation (in Muluk, 2007: 13), explains the role of society, which is based on the power of society to determine an end product. According to Arnstein (1969), society participation can be divided into several levels. According to Sherry Arnstein (1969), the level of participation starts from the lowest to the highest. Manipulation can be interpreted as no communication, let alone dialogue between the government and society; Therapy (therapy) means that there is communication but is still limited, the initiative comes from the government and is only one way; Information (information) communication has started to occur a lot but is still one-way; Consultation (consultation) has taken place and two-way communication; Placation (penentraman) communication has been going well and there have been negotiations between the society and the government; partnership (partnership) is a condition in which the government and society are equal partners; Delegated Power (delegation of authority) means that the government gives authority to the society to take care of some of his own needs; and Citizen Control (citizen supervision) at this level the society controls public policy starting from the formulation, implementation, evaluation and control (supervision). Arnstein also divides the eight levels of society participation into 3 (three) categories including: (1) Non-Participation Level (no participation) consisting of the first and second ladder (Therapy and Manipulation) whose objectives are to educate and treat the society; (2) Level of Tokenism (Degree of participation mark) which consists of the third ladder (Information), fourth (Consultation), fifth (Placation), and sixth (Partnership), namely the level of participation where the public is heard and has an opinion but does not have the ability to get guarantees that decision-makers will consider their views. At this level, public participation is unlikely to bring about change in society; and (3) the degree of Citizen Power, society influences the decision-making process by carrying out partnerships, delegation of power, and society supervision. The level of society power includes the seventh ladder (Delegated Power) and the eighth ladder (Citizen Control). On the seventh and eighth steps, the society has full power in voicing and in the decision-making process.

Society participation in the Kletek village in the village fund program illustrates that there are still many problems caused. This is if it is related to the level of participation according to Sherry Arnstein (1969), the society participation that occurs in the Kletek village is at the sixth level (Partnership), namely the level of participation where the society is heard and has an opinion but cannot have the assurance that decision-makers will consider their views. At this level society, participation has very little chance of bringing about change in society. 


\section{Conclusion}

Based on the results of the research and discussion previously described regarding society participation in the village fund program for development in Kletek village, in this study it can be concluded that society participation in the decision-making stage is still very minimal, this is based on the attitude of the village government not conducting network aspirations from the hamlet level so that many society members who live in the village of Kletek do not know about the aspiration gathering meeting at the hamlet level. Society participation in the implementation stage shows that society does not play an active role in participating in work. According to society, everything has been budgeted so that it must be paid. This is not without reason because it has become the mindset of most citizens. In terms of supervising the physical work of development, the society feels that it is good enough to supervise the physical construction work because the society as the target of development must also supervise the construction. Participation in taking benefits is deemed inappropriate because in some cases, assistance is not provided when the society needs it, besides emotional closeness is still the key so that someone can receive assistance from the village government, this is no longer a secret. This mindset has been embedded in the society's development. Participation in the evaluation is very invisible, this is due to the absence of an information board so that the society does not know how much village funds are received and managed by the Kletek village. In addition, the physical buildings that have been built are still in use even though some parts of the deck building have been damaged and not repaired.

\section{References}

Abe, Alexander. (2005). Perencanaan daerah partisipatif. Yogyakarta. Pembaharuan Press. hlm. 18

Arnstein, Sherry R. (1969). A ladder of citizen participation: journal of the american planning association. 35: 4, 216-224.

Asnaini. (2012). Manajemen keuangan. Yogyakarta. Teras.

Asshiddiqie, Jimly. (2008). Pokok-pokok hukum tata negara Indonesia pasca reformasi. Jakarta. PT. Bhuana Ilmu Komputer. hlm. 833-834.

Atmadja, Arifin P Soeria. (1986). Pertanggungjawaban keuangan negara. Jakarta. PT. Gramedia. hlm.49.

Bintarto, R. (1986). Desa-kota. Bandung. Alumni. hlm. 11-12

Cohen, J.M \& Uphoff N.T., (1977). Rural development participation concept and measures for project design implementation and evaluation. https://www.Researchgate.net/publication/37882394_Rural_DevelopmentParticipation_Conce ptand_Measuresfor_Project_Design_Implementation_and_Evaluation/word.,(diakses tanggal 1 oktober 2019).

Daldjoeni, N. (1987). Geografi kota dan desa. Bandung: Alumni.

Dewi, I. K. (2019). The role of village community empowerment institution in Galanti village development of Buton district. Jurnal Hukum Volkgeist, 4(1), 17-24.

Echols, John M \& Shadily, Hassan. (2000). Kamus Inggris indonesia an English-Indonesia dictionary. Jakarta : PT. Gramedia.

Isbandi, Adi Rukminto. (2007). Perencanaan partisipatoris berbasis aset komunitas: dari pemikiran menuju penerapan. Depok: FISIP UI Press.

Jalal, Fasli \& Supriadi, Dedi. (2001). Reformasi pendidikan dalam konteks otonomi daerah. Yogyakarta. Adicita Karya Nusa.

Mohammad, Roni, Ferlin Anwar dan Muhammad Obie. (2020). Poeverty and its eradication in Indonesia: A Case of Implementation of Village Fund Program in Gorontalo Regency. Indternational Journal of Management, Innovation \& Entrepreneural Research, 6(1), 15-22.

Muluk, Khairul. (2007). Desentralisasi dan pemerintah daerah. Edisi Pertama. Malang. Bayumedia Publishing dengan Center for Indonesian Reform.

Najih, Mokh. Wiryani, Fifik. Sirajuddin. Sopanah, Ana. (2006). Hak rakyat mengontrol negara: membangun model partisipasi masyarakat dalam penyelenggaraan otonomi daerah. YAPPIKA. Jakarta.

Nastiti, M., \& Sunyoto, A. (2012). Perancangan Aplikasi Manajemen Keuangan Pribadi Berbasis Android. Data Manajemen dan Teknologi Informasi (DASI), 13(2), 38. 
Nugroho A. (2007). Analisis dan perancangan sistem informasi dengan metodologi berorientasi objek (Edisi Revisi). Bandung: Informatika.

Purnomo, W. E., Wahyuni, D., \& Paramita, W. (2016, May). The village people empowerment to increase social welfare. InInternational Conference On Law, Business and Governance (ICon$L B G)($ p. 45).

Putra, Chandra Kusuma. Pratiwi, Ratih Nur \& Suwondo. (2013). Pengelolaan alokasi dana desa dalam pemberdayaan masyarakat desa (Studi pada desa Wonorejo kecamatan Singosari Kabupaten Malang). Skripsi. Jurnal Administrasi Publik (JAP), 1(6), 1203-1212

Ramadhan, Perdana dan Fitanto Bahtiar. (2006). Distribusi kewenangan kabupaten-desa telaah kasus Implementasi Otonomi Daerah. Focal Point SPOD Fakultas Ekonomi Universitas Brawijaya, Malang.

Riyadi \& Bratakusuma, Deddy Supriyadi. (2005). Perencanaan pembangunan daerah. Jakarta. PT Gramedia Pustaka Utama.

Samosir, D. (2020). analysis effectiveness of use of alocation village funds and village funds in Samba Danum Village Katingan Tengah Disrict on 2018. KnE Social Sciences, 2020, kss-v4i6.

Sugiyah. (2001). Partisipasi komite sekolah dalam penyelenggaraan rintisan sekolah bertaraf internasional di Sekolah Dasar (SD) Negeri IV Wates, Kabupaten Kulon Progo. Tesis. PPs UNY.

Sugiyono. (2010). Metode penelitian pendidikan pendekatan kuantitatif, kualitatif, dan $R \& D$. Bandung. Alfabeta. Hlm 246.

Sulaiman, Alfin. (2011). Keuangan negara pada BUMN dalam perspektif ilmu hukum. Bandung. PT. Alumni.

Sumaryadi, I Nyoman. (2010). Sosiologi pemerintahan. Bogor: Ghalia Indonesia

Sumpeno, Wahjudin. (2011). Perencanaan desa terpadu. Banda Aceh ,Reinforcement Action and Development. Hlm. 3

Syafi' I, Inu Kencana \& Azikin, Andi. (2007). Perbandingan pemerintahan. Bandung. PT. Refika Aditama

Syahruddin, J., Effendy, K., Hamdi, M., \& Soemartono, T. (2019). Implementation of Transmigration Settlement Unit Transformation to Village Policy for Increasing Society Welfare in Indonesia. Journal of Public Administration and Governance, 9(2), 367-386.

Tangkilisan, Hessel Nogi S. (2005). Manajemen publik. Jakarta. Grasindo.

Tilaar, H.A.R.. (2009). Kekuasaan dan pendidikan: kajian menejemen pendidikan nasional dalam pusaran kekuasaan . Jakarta: Rineka Cipta.

Tjandra, W Riawan. (2006). Hukum keuangan negara. PT. Grasindo, Jakarta, 2006, hlm. 1-2.

Wahab, Solichin Abdul. (2002). Analisis kebijaksanaan dari formulasi ke implementasi kebijaksanaan negara. Edisi Kedua. Jakarta. Bumi Aksara.

Widjaja, HAW. (2003). Otonomi desa. Jakarta: Raja Grafindo Persada. Hlm. 3. Statutory Regulations.

Peraturan Menteri Desa, pembangunan daerah tertinggal dan transmigrasi (PERMENDES PDTT) Nomor 16 tahun 2018 tentang prioritas penggunaan dana desa tahun 2019. Melalui https://peraturan.bpk.go.id/Home/ Details/139734/permendes-pdtt-no-16-tahun-2018. (diakses tanggal 02-08-2020).

Peraturan Menteri Keuangan (PMK) nomor 50 tahun 2017 tentang pengelolaan transfer ke daerah dan dana desa. Melalui https://jdih.kemenkeu. go.id/fullText/2017/50 PMK.07 2017Per.pdf. (diakses tanggal 02-08-2020).

Peraturan Pemerintah nomor 72 tahun 2005 tentang desa. Melalui https://m. hukumonline.com/pusatdata/detail/24508/node/707/pp-no-72-tahun-2005-desa. (diakses tanggal 24-07-2020).

Peraturan Pemerintah Republik Indonesia Nomor 60 tahun 2014 tentang dana desa yang bersumber dari anggaran pendapatan dan belanja negara. Melalui https://ppidkemkominfo.files.wordpress.com/2016/08/pp-no-60-th-2014-ttg-dana-sumberapbn.pdf. (diakses tanggal 27-07-2020).

Peraturan Pemerintah Republik Indonesia nomor 8 tahun 2016 tentang perubahan kedua atas Peraturan Pemerintah nomor 60 tahun 2014 tentang dana desa yang bersumber dari anggaran pendapatan dan belanja negara. Melalui https://jdih.kemenkeu.go.id/fullText/2016/8TAHUN2016PP.pdf. (diakses tang gal 30-07-2020). 
Undang-Undang (UU) Nomor 23 tahun 2014 tentang Pemerintahan Daerah. Melalui https://pih.kemlu.go.id/files/UU0232014.pdf

Undang-Undang nomor 28 tahun 1999 tentang penyelenggaraan pemerintahan yang bersih dan bebas dari kolusi, korupsi, dan nepotisme. Melalui https://kpk.go.id/gratifikasi/BP/uu_28_1999.pdf. (diakses tanggal 20-07-2020).

Undang-Undang Nomor 6 tahun 2014 tentang Desa. Melalui https://www. hukumonline.com/pusatdata/detail/1t52e8c12d3ce4a/undang-undang-nomor-6-tahun-2014. (diakses tanggal 30-07-2020). 